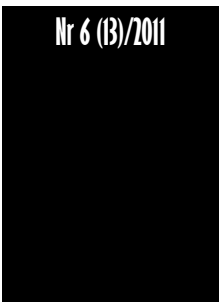

\title{
Indywidualizm amerykańskiej Starej Prawicy
}

\footnotetext{
D
} ychotomia pomiędzy amerykańskim i europejskim rozumieniem pojęć konserwatyzmu i liberalizmu jest zjawiskiem powszechnie znanym, lecz stosunkowo rzadko tłumaczy się tę różnicę. Jest to jednak kwestia kluczowa dla zrozumienia fenomenu podejścia indywidualistycznego na prawym brzegu amerykańskiej sceny politycznej. Konserwatyzm amerykański odwołuje się bowiem do zdobyczy rewolucji amerykańskiej, do prymatu praw naturalnych, z prawem do wolności osobistej na czele. Konserwatyzm w wydaniu tradycyjnym skłania się raczej ku stosunkowi władzy i instytucji Kościoła, arystokratycznej hierarchii, czy do wartości płynącej z utrzymania starego porządku. Robert M. Crunden we wstępie do książki The Superflous Men pisze przewrotnie, że rewolucja amerykańska ustanowiła rząd prawdziwie liberalny, a zadaniem konserwatystów było utrzymanie tego stanu rzeczy. R. M. Crunden charakteryzuje indywidualistycznych konserwatystów następującymi słowami: „Wierzą, że najważniejsze rzeczy w życiu są domeną sfery prywatnej, nie podatnej na interwencję rządu. Rząd Stanów Zjednoczonych powinien chronić własności i cnót, i na tym poprzestać. Nie powinien preferować jednej religii kosztem drugiej. Nie powinien regulować. Nie powinien redystrybuować dochodu i biurokratyzować pomocy społecznej. Nie powinien wpływać na produkcję rolną [...] Nie powinien promować sztucznej jedności w niejednorodnym kraju, lecz powinien pozwalać jednostkom lokalnym działać na rzecz pokojowego regionalizmu" ${ }^{11}$. Jest to konserwatyzm róż-

${ }^{1}$ R. M. Crunden, The Superflous Men, Wilmington 1999, s. 26. 
ny w wielu aspektach od austriackiego konserwatyzmu Klemensa Lothara von Metternicha, orientalnego konserwatyzmu chińskiego, japońskiego czy indyjskiego. Każdy z nich ma swoje priorytety.

\section{Korzenie i pryncypia}

Aż do połowy lat 50. XX wieku centralną ideą scalającą amerykańskich konserwatystów była idea wolności od omnipotentnego rządu. Konserwatyści i indywidualiści, zjednoczeni pod szyldem Starej Prawicy nie mieli złudzeń o co toczy się stawka, a była to walka o kształt państwa - republiki, w której podmiotem jest jednostka i jej naturalne prawa, nie zaś motywowany popędami kolektyw. Tak istotny dla indywidualistów mit amerykańskiej wyjątkowości (ang. American exceptionalism) musiał się zderzyć z forsowanym szczególnie mocno w okresie Nowego Ładu, europejskim modelem państwa opiekuńczego. Wielka indywidualistka, przedstawicielka Starej Prawicy, Rose Wilder Lane w 1945 roku otwarcie opowiadała się za embargiem na import europejskiego etatyzmu: „Przez pół wieku reakcyjne prądy rodem z Europy zmieniały amerykańskie myślenie o podstawach socjalizmu. W miastach i stanach obie partie zaczęły socjalizować Amerykę na wzór kaizerowskich Niemiec, propagując: prawo do pomocy socjalnej, prawa pracownicze, regulacje płacowe, emerytury i tzw. własność publiczną. Jedenaście lat temu wznoszący na fali socjalizm stał się bronią rządu federalnego, a Amerykanie nagle postawieni zostali przed pytaniem o wybór między amerykańskim indywidualizmem a europejskim narodowym socjalizmem"2.

Podejście indywidualistyczne, postulujące wolnorynkowy leseferyzm i antyimperializm ma swoje korzenie już w rewolucji amerykańskiej: Thomas Paine, Thomas Jefferson, William Lloyd Garrison, a także radykalni abolicjoniści - wszyscy oni byli indywidualistami prowadzącymi walkę o wolność, przeciwko wszelkim formom przywilejów nadawanych przez państwo. Murray Rothbard w Betrayal of the American Right wspomina także o indywidualistycznych korzeniach kupców i przemysłowców, jak Edward Atkinson, który stojąc na czele Ligi Antyimperialistycznej żarliwie sprzeciwiał się angażowaniu się w wojnę z Hiszpanią, a także pisał listy do żołnierzy, by nie

${ }^{2}$ R. W. Lane, Give me Liberty, Los Angeles 1945, cyt. za: J. Raimondo, Reclaiming the American Right, Bulringame 1993, s. 2. 
brali udziału w operacji na Filipinach, czego efektem była konfiskata listów przez urząd pocztowy ${ }^{3}$.

\section{Indywidualiści, ich sojusznicy i wrogowie}

Uczciwie należy przyznać, że u progu wybuchu I wojny światowej obóz indywidualistyczny nie był jedynym, który sprzeciwiał się interwencjom zbrojnym i postulował tradycyjny izolacjonizm, wywodzący się z doktryny Monroe'a. Taki pogląd prezentowali wówczas również socjaliści i progresiści, stąd wszystkie grupy opozycyjne wobec wojny określano mianem lewicy. Wielki rozmach propagandy wojennej, związana z tym presja i jedność stanowisk obu partii, wykreował tak egzotyczną koalicję, pomimo iż indywidualiści prezentowali koncepcje w wielu dziedzinach skrajnie odmienne od socjalistów. Czas ten był wielką traumą dla grup opozycyjnych wobec wojny, których nazywano niewybrednie „anty-patriotami”. Ta luźna koalicja była oderwana od procesu politycznego, przeciwna polityce obu partii, których sojusz z wielkim biznesem skutkował regulowaniem gospodarki. W Kongresie jedynymi reprezentantami antywojennych indywidualistów pozostali senatorzy: Robert LaFolette (republikanin), William E. Borah (republikanin), James A. Reed (demokrata).

Wspominany obraz indywidualistów jako „ludzi lewicy”, powstały ze względu na ich bezkompromisową postawę wobec zaangażowania wojennego, dopełnił jeszcze ich ostry sprzeciw wobec wprowadzanej, przez rządzącą w latach 20. XX wieku Partię Republikańską, prohibicji oraz szkodliwych regulacji na rzecz wielkiego biznesu. Z punktu widzenia indywidualistów, najbliższym odłamem politycznym było wówczas konserwatywne „burbońskie” skrzydło Partii Demokratycznej, opowiadające się za wolnym handlem i za ograniczonym rządem, a przeciwko interwencji państwa. Właśnie ta grupa, pod przewodnictwem Charlesa Michelsona, Jouett Shousa i Johna Raskoba, atakowała prezydenta Herberta Hoovera za prohibicję i budowanie wielkiego rządu w latach 20 .

W okresie międzywojennym środowisko indywidualistów posiadało swoją silną reprezentację w świecie intelektualnym. Na jej czele stał Henry Louis Mencken, wpływowy dziennikarz, eseista, satyryk, cięty krytyk amerykańskiego życia kulturalnego i politycznego. H. L. Menckena można nazwać

\footnotetext{
${ }^{3}$ M. N. Rothbard, The Betrayal of the American Right, Auburn 2007, s. 4.
} 
radykalnym libertarianinem, jako że domagał się nieograniczonej wolności jednostki. Pisał o tym do swojego przyjaciela Hamiltona Owensa: „Wierzę tylko w jedną rzecz i jest nią wolność człowieka. Jeśli człowiek otrzymał godność, mogło się to stać jedynie jeśli został obdarzony absolutną wolnością do myślenia i wyrażania cokolwiek chce wyrazić. Człowiek może być pewnym swej wolności, jedynie jeśli została ona dana wszystkim ludziom. [...] Jestem radykalnym libertarianinem, wierzę w absolutną wolność słowa"4.

Jego zaangażowanie $\mathrm{w}$ sprawy polityczne wynikało $\mathrm{z}$ traumy po doświadczeniach I wojny światowej oraz despotyzmu prohibicji, której zaciekle się sprzeciwiał. Od 1924 roku wydawał magazyn „The American Mercury”, w którym publikowali wszyscy wojenni rewizjoniści, kulturowi nonkonformiści, a także wolnościowcy. Krytyk literacki Samuel Putnam nazwał H. L. Menckena mianem swoistego anarchisty-torysa, podsumowując jego dorobek jako lidera intelektualnego lat 20. Innym anarchistą-torysem, którego dorobek odbił swoje piętno w latach międzywojennych, był przyjaciel H. L. Menckena, Albert Jay Nock, indywidualista i radykalny zwolennik leseferyzmu. W latach 1920-1924 współwydawał tygodnik „The Freeman”, który stał się tubą radykalnej anty-establishmentowej opozycji. Sam A. J. Nock nie uważał siebie za liberała lecz za radykała, powiadał: „to była wojna liberałów i pokój liberałów, a obecny stan rzeczy jest wynikiem długiego, przytłaczającego i kosztownego eksperymentu liberalizmu u władzy"5.

A. J. Nock jak nikt inny w tamtym czasie przyczynił się do ugruntowania systemowej teorii libertarianizmu. W serii esejów $O$ państwie opublikowanej w 1923 roku w „The Freeman” A. J. Nock oparł się na teoriach Herberta Spencera i niemieckiego socjologa Franza Oppenheimera, który rozważał dwie drogi zdobywania majątku: pokojową, poprzez środki ekonomiczne oraz działanie siłowe, za pomocą środków politycznych. F. Oppenheimer państwo nazywał „organizacją środków politycznych”, zaś A. J. Nock definiował je jako instytucję „przyjmującą i praktykującą monopol na przemoc”, która „zabrania mordować prywatnie, lecz sama uprawia morderstwo na masową skalę. Zakazuje prywatnej kradzieży, lecz samo kładzie ręce na czym zechce"6.

Związany później ze Starą Prawicą pisarz Oswald Garrison Villard, opowiadający się za wojennym rewizjonizmem, przeciwko postanowieniom traktatu wersalskiego, w latach 20 . uznawany był przez część konserwatystów za „pro-niemieckiego, bolszewickiego pacyfistę”. Podobny los spotykał

4 Ibidem, s. 15.

${ }^{5}$ R. M. Crunden, The Mind and Art of Albert Jay Nock, Chicago 1964, s. 77.

${ }^{6}$ A. J. Nock, Our Enemy, the State, New York 1922, cyt. za: M. N. Rothbard, op. cit., s. 18. 
wielu izolacjonistycznych indywidualistów, którzy wbrew głównemu nurtowi tkwili na swoich pozycjach.

\section{Indywidualiści w obliczu Nowego tadu}

W latach 20. indywidualiści, jak H. L. Mencken, A. J. Nock czy O. G. Villard, uważani byli za ludzi lewicy, ponieważ ostro sprzeciwiali się establishmentowi rządowemu, jego rozrostowi oraz związkom z wielkim biznesem. Negowali także imperializm i zaangażowanie międzynarodowe rządu USA. Ich umiejscowienie na scenie politycznej zmieniło się o 180 stopni wraz z nastaniem Nowego Ładu. Nagle z „ludzi lewicy” stali się „skrajnymi prawicowcami”. Dla indywidualistów Nowy Ład był logiczną kontynuacją hooveryzmu i dziedzictwa I wojny światowej - postrzegany był jako budowa państwa korporacyjnego, popieranego przez wielki biznes i wielkie związki zawodowe, przy wsparciu liberalnych intelektualistów. W powszechnej opinii środowiska indywidualistów był to wręcz faszyzm u bram Ameryki. Inaczej spoglądali na to zjawisko socjaliści i progresiści, którzy nie tylko poparli, ale wręcz aktywnie włączyli się w budowę New Deal'u. To właśnie ze strony dawnych antyimperialistycznych nieformalnych koalicjantów padały najostrzejsze zarzuty wobec integralnej postawy indywidualistów: nazywano ich "reakcjonistami”, „faszystami”, a nawet „neandertalczykami”. W ciągu zaledwie jednej dekady indywidualiści nie zmieniając swoich poglądów ani na jotę zostali przemalowani z lewicowców na ekstremalnych prawicowców ${ }^{7}$, co dosyć dosadnie pokazuje ułomność tak uproszczonego widzenia politycznego spektrum.

W obliczu narastającego zagrożenia dla wolności, sojusznikiem indywidualistów stali się ich dotychczasowi przeciwnicy, konserwatyści z Partii Republikańskiej. Alians ten przyjął nazwę Starej Prawicy, a jej głównym celem było odzyskanie utraconej wolności. Dramatyczny rozrost instytucji państwowych i wdrażanie coraz to nowych programów społecznych, także wśród konserwatystów budziły trwogę przed potężnym rządem. Aby przeciwstawić się tym tendencjom przejęli retorykę indywidualistów, których wcześniej ignorowali. Nawet sam Herbert Hoover, który w okresie swojej prezydentury wyścielił niejako drogę Franklinowi Delano Rooseveltovi, przeszedł na pozycje niemal libertariańskie, co wyraził w wydanej w 1934 roku książce The Challange to Liberty. Także konserwatywni demokraci wyrażali sprzeciw wo-

\footnotetext{
${ }^{7}$ Ibidem, s. 25.
} 
bec Nowego Ładu, działając w American Liberty League, organizacji, której głównym przesłaniem była obrona wartości konstytucyjnych. Tym, co w opinii indywidualistów przeżerało państwo amerykańskie również przed nastaniem Nowego Ładu, było jego konsumowanie przez grupy wpływu, które domagały się realizowania swoich interesów przy użyciu instrumentów władzy. R. M. Crunden pisał: „Coolidge robił co tylko potrafił by pomóc biznesowi, zaś Roosevelt robił dokładnie to samo... innymi słowy, większość Amerykanów chciała, aby rząd pomagał tylko im samym".

\section{Izolacjoniści czasów militarnych}

Indywidualiści amerykańscy w polityce zagranicznej nawiązywali do tradycji nieinterwencji, określanej często mianem izolacjonizmu. Sprzeciwiali się angażowaniu się Stanów Zjednoczonych w konflikty w odległych częściach świata, argumentując, że Konstytucja obliguje jedynie do obrony kraju przed atakiem agresora. W okresie międzywojennym izolacjonizm uważany był za pogląd lewicowy, a nawet jego leseferystyczni zwolennicy określani byli mianem „lewaków” czy członków komunistycznej „czerwonej sieci”, jak określano wolnorynkowego senatora Williama E. Boraha9. Jednakże od czasu Nowego Ładu mamy do czynienia z wielkim zwrotem w polityce zagranicznej, kiedy to dotychczas izolacjonistyczna lewica staje na pierwszym froncie amerykańskiego imperializmu, kierując się mesjanistyczną wizją ratowania zagrożonego ludu i demokracji na świecie. Wreszcie prezydent F. D. Roosevelt decyduje się na zaangażowanie militarne na Dalekim Wschodzie i w Europie. Wojna z Niemcami i Japonią staje się dla byłych oponentów traktatu wersalskiego dziejową misją na rzecz „powstrzymania faszyzmu”. Dawni rewizjonistyczni sojusznicy denuncjowali izolacjonistycznych indywidualistów jako „reakcjonistów”, „faszystów”, „antysemitów”, a nawet „zwolenników Goebbelsa". Największym zapałem w tej dziedzinie odznaczała się Komunistyczna Partia Stanów Zjednoczonych, szczególnie po ataku hitlerowskich Niemiec na ZSRR w 1941 roku. Komuniści samozwańczo mianują się ober-patriotami ogłaszając, że „komunizm jest dwudziestowiecznym amerykanizmem”"

Po wybuchu II wojny światowej mamy do czynienia z ogromną nagonką wobec przeciwników wojennego zaangażowania, następuje cała fala zwol-

${ }^{8}$ R. M. Crunden, The Mind and Art..., s. 164.

${ }_{9}$ M. N. Rothbard, op. cit., s. 33.

10 Ibidem, s. 34. 
nień z redakcji czasopism. O. G. Villard, wyrzucony z redakcji „The Nation” za krytykę militarystycznej polityki F. D. Roosevelta, zostaje na koniec oskarżony o stwarzanie „zagrożenia większego niż faszyzm”, zaś jego polityka za „dokładnie taką, jaką wspiera propaganda nazistów w Ameryce". Podobny los spotyka Johna T. Flynna w „New Republic” oraz H. L. Menckena i A. J. Nocka w „American Mercury”. Za opozycyjny stosunek wobec wojny Frank Chodorov zostaje zwolniony z pozycji rektora nowojorskiej Henry George School. Padają oskarżenia wobec przeciwników wojny o bycie „nazistowskim pasem transmisyjnym", a nawet o działalność agenturalną na rzecz Japonii lub Niemiec $^{11}$. Największa organizacja przeciwna wojnie, America First Committee, jest prześladowana i ma wyraźne problemy przy wynajmowaniu hal na spotkania publiczne $\mathrm{w}$ wielu miastach. Częstym zarzutem w tamtych czasach staje się antysemityzm, co w obliczu obecności Żydów w America First Committee wydaje się być kuriozalne. M. Rothbard w swojej książce przyznaje, że wynikało to z presji wywieranej przez licznych Żydów, którzy dotknięci tragedią swojego narodu domagali się interwencji zbrojnej, aby ocalić jego przedstawicieli.

\section{Przeciwko wojnie nieustającej}

Zgiełk wokół wojny, jako koniecznej obrony demokracji przed faszyzmem, zdaje się jednocześnie pomijać kwestię fundamentalną dla amerykańskiego konserwatywnego indywidualizmu, a mianowicie oddania pod kuratelę rządu tych obszarów, które naturalnie były domeną jednostek. W wymowny sposób pisał o tym John T. Flynn w As We Go Marching, gdzie określał New Deal jako amerykański faszyzm, tzw. dobry faszyzm: „Związki zawodowe, przedstawiciele izb rzemieślniczych, brokerzy, bankierzy, kupcy i ich klienci, przyłączyli się w całym kraju do wielkich parad na rzecz przyjęcia wielkiego programu"12.

J. T. Flynn słusznie przewidywał także, że rząd nie zrezygnuje z wielkich wydatków militarnych nawet po wojnie, co Charles A. Beard nazwał „niekończącą się wojną o niekończący się pokój”. J. F. Flynn zauważył także, że imperializm będzie podtrzymywany szukaniem wrogów. Proroctwo to spełnia się wraz z końcem wojny i rozpoczęciem kolejnej, tym razem zimnej woj-

\footnotetext{
11 Ibidem, s. 41.

12 J. T. Flynn, As We Go Marching, Garden City 1944, s. 193.
} 
ny. Indywidualistycznych pozycji w tym czasie strzeże grupa polityków Partii Republikańskiej, skupiona wokół senatora Roberta Tafta. Ten niedoszły kandydat Partii Republikańskiej na urząd prezydenta USA w 1952 roku był, jak pisze Russel Kirk w jego biografii, „[...] dzięki swojej inteligencji i integryzmowi, najwybitniejszą osobistością publiczną swojej epoki. Był silnym i prostolinijnym człowiekiem, który wielokrotnie odmawiał władzy wykonawczej, a pomimo to zostanie zapamiętany bardziej niż wielu prezydentów, którzy pozostawili po sobie tylko nazwiska"13. Jego wielka polityczna odwaga pozwalała mu sprzeciwiać się zaognianiu zimnej wojny, a w szczególności: planowi Marshalla, doktrynie Trumana, pomocy dla Grecji i Turcji, powstaniu NATO, a także wojnie w Korei. Był przeciwny utworzeniu NATO argumentując, że tworzenie tak szerokiego sojuszu spowoduje zagrożenie inwazji ZSRR lub jego sojuszników, co będzie osią ich polityki obronnej. Twierdził, że zbrojenie połowy świata przeciw drugiej połowie jest zupełnie niezgodne z duchem karty Narodów Zjednoczonych. Wiedzie to ku wyścigowi zbrojeń, co w przeszłości prowadziło do wojen. Uważał, że zbliża nas to do III wojny światowej, a nie do pokoju. W 1950 roku sprzeciwiał się wspieraniu francuskiej armii w Indochinach, a także wspieraniu Chiang Kai-Sheka pragnącego powrócić do władzy w Chinach. W tym samym roku udało się jednym głosem odrzucić sześćdziesięciomilionowy plan dla Korei Południowej, co było ostatnim zwycięstwem Starej Prawicy. ONZ było wówczas elementem rozgrywanym przez USA. R. Taft argumentował, że wojna w Korei nie wpisywała się w interesy USA, mogła także tworzyć zagrożenie ze strony bloku sowieckiego. Wojna ta była ponadto samowolką prezydenta, gdyż wypowiedziana została bez zgody Kongresu. Senator R. Taft w jednym ze swoich ostatnich przemówień skupił się na krytyce amerykańskiej polityki w Azji Południowo-Wschodniej. Amerykanie akurat zwiększyli o 70\% wydatki na pomoc francuskiemu rządowi marionetkowemu w Indochinach (przeciw siłom Ho Chi Minha). Wyrażał obawę, że polityka sekretarza stanu Johna Fostera Dullesa po pewnej porażce Francuzów, doprowadzi do wymiany ich na Amerykanów i wysłania żołnierzy do Wietnamu, do walki z guerillami. W jego opinii taktyka walki z ZSRR na innych kontynentach mogła jedynie zaostrzyć konflikt, być bardzo kosztowna dla obywateli USA i ograniczyć ich wolności obywatelskie $^{14}$. Przedstawiciele Starej Prawicy w szczególności zwracali uwagę na zagrożenie wynikające z przyjęcia paradygmatu permanentnej wojny, do

${ }^{13}$ R. Kirk, J. McClellan, The Political Principles of Robert A. Taft, New York 1967.

${ }^{14}$ M. N. Rothbard, op. cit., s. 88-94. 
czego parła ówczesna klasa rządząca. Garet Garrett pisał w 1953 roku w swojej książce pt. The People's Pottage: „Nie jesteśmy już w stanie wybierać między pokojem a wojną. Znaleźliśmy się w stanie wojny ustawicznej. Gdziekolwiek i kiedykolwiek sowieccy agresorzy zaatakują — my musimy im wyjść naprzeciw. Jesteśmy związani doktryną Trumana, naszą obecnością w innych krajach, NATO, a także Paktem Pacyfiku. W takich warunkach kwestie wewnętrzne pozostają relatywnie nieważne - w stanie permanentnego zagrożenia wojennego można konfiskować własność prywatną, eliminować wolności obywatelskie, a nawet ustanawiać przymusowe roboty publiczne"15.

\section{Zmierzch Starej i narodziny Nowej Prawicy}

We wstępie do Reclaiming the American Right Justin Raimondo zastanawia się „co poszło źle?”16, w kontekście opanowania prawej strony amerykańskiej sceny politycznej przez tzw. Nową Prawicę, której zarodkiem był powstały w dwa lata po śmierci senatora Tafta (w 1953 roku) magazyn "National Review". Odpowiedź na pytanie, dlaczego perspektywa indywidualistyczna na prawicy na długie lata odeszła w cień, sprowadza się do kontekstu historycznego. Trwająca przez ponad 40 lat zimna wojna świata zachodniego ze światem komunistycznym, przełożyła się również na amerykańską scenę polityczną, opanowując także jej prawą stronę. Neokonserwatyzm zaproponował prostą wizję jaką był antykomunistyczny mesjanizm. Wpisywał się tym samym w logikę swoich czasów, kiedy ludzie domagali się przede wszystkim obietnic bezpieczeństwa.

J. Raimondo zauważa, że w porównaniu z komunizmem mamy tu do czynienia ze zmianą treści, lecz niekoniecznie formy. Liczy się przede wszystkim cel, a w mniejszym stopniu środki do jego osiągnięcia. Nie jest przypadkiem, że wśród ojców założycieli Nowej Prawicy odnajdujemy tzw. nawróconych komunistów, z byłym trockistą Jamesem Burnhamem na czele. Jego postulat manichejskiej walki Zachodu z komunizmem, nawet za cenę częściowej utraty wolności, mówi nam, jak bardzo różni się perspektywa neokonserwatyzmu ufundowanego na konfrontacji z wrogiem, od stawiającego na fundament wolności i literę Konstytucji konserwatyzmu indywidualistycznego. Ta swoista utrata kontaktu z tradycyjnymi wartościami amerykańskiego konser-

${ }_{15}$ G. Garrett, The People's Pottage, Caldwell 1953, s. 139-140.

16 J. Raimondo, Reclaiming the American Right. The lost legacy of the conservative movement, Burlingame 1993, s. 1. 
watyzmu jest również widoczna w dzisiejszej polityce neokonserwatystów, którzy w imię walki z globalnym terroryzmem gotowi są pójść na kompromis w kwestiach widzianych przez indywidualistów jako te rangi najwyższej. Pryncypia Starej Prawicy zdają się jednak wracać do powszechnego obiegu, czego świadectwem jest wielka popularność Rona Paula i, skupionego wokół idei rządu ograniczonego, ruchu Tea Party. Zaryzykować można stwierdzenie, że pomimo porażki Starej Prawicy i faktycznym zniknięciu ze sceny politycznej w drugiej połowie lat 50., reprezentowane przez nią idee są nadal żywe i w nieodległej przyszłości mogą zmienić Amerykę.

Individualism of so called „Old Right Wing” in America

The article is dedicated to the philosophy and history of the Old Right movement in United States of America. At the beginning, author discusses the historical roots, ideological structure, and principles of the Old Right with important figures behind it. The next part of the article is devoted to the presence of the movement in the American political arena: it's alliances, enemies, and political representation. A substantial part of the article is based on the Old Right's arguments against President Roosevelt's New Deal in all it's aspects. The consequent anti-interventionist position of the Old Right pushed them to opposition to the US military presence in World War I and World War II. That unique but ideologically coherent standpoint is discussed in the later part of the article. It shows the popular perception of the anti-interventionist arguments, revealing not widely known facts about it. The question of the American military interventions reflected by the classical liberal principles, dominates the last part of the article. Author discusses the theory of the cold war and emerge of the New Right as a cause of the Old Right's defeat. Finally, he summarizes the Old Right's political positions, and predicts possible developments of that ideas in future. 